\title{
Japanese encephalitis
}

\author{
Novie H. Rampengan \\ Bagian Ilmu Kesehatan Anak \\ Fakultas Kedokteran Universitas Sam Ratulangi Manado \\ Email: novierampengan@yahoo.com
}

\begin{abstract}
Japanese encephalitis (JE) is an acute infective disease in the central nervous system. Pigs and birds are the main reservoirs of JE viruses, albeit, there is no transmission from human to human with mosquito bites. Clinical manifestations of JE in human vary from mild symptoms like rhinitis until severe symptoms, and even death. Incubation period of JE varies from 4 until 14 days. Development of JE symptoms are divided into 4 stadiums, as follows: prodormal, acute, sub-acute, and convalescent. Diagnosis is based on anamnesis about fever and the presence of pig farm around the house, and physical examination consisted of increased intra-cranial pressure and decreased consciousness, meanwhile, the definite diagnosis is confirmed with virus isolation either IgM capture ELISA test from serum or cerebrospinal fluid; both have sensitivity almost $100 \%$. Treatment of JE is only symptomatic and supportive. Prevention and erradication of JE virus are aimed to human, mosquito Culex as vector and its larvae, and pig as the reservoir. Japanese encephalitis can be prevented with immunization. In severe cases, sequelae are found around $40 \%-75 \%$.
\end{abstract}

Keywords: Japanese encephalitis, culex mosquito, pig farm, vaccination

\begin{abstract}
Abstrak: Japanese encephalitis (JE) merupakan penyakit infeksi akut pada SSP. Babi dan unggas merupakan reservoir virus ini, namun tidak terjadi penularan dari manusia ke manusia lain melalui gigitan nyamuk. Manifestasi klinis penyakit JE pada manusia bervariasi, mulai dari gejala ringan seperti demam flu biasa sampai berat bahkan kematian. Masa inkubasi JE bervariasi antara 4 sampai 14 hari. Perkembangan gejala JE terbagi atas 4 stadium yaitu stadium prodormal, akut, sub-akut, dan konvalesen. Diagnosis pasti dengan anamnesis adanya perternakan babi disekitar rumah dan demam, pemeriksaan fisik terdapat peningkatan tekanan intra kranial serta penurunan kesadaran, dan diagnosis pasti dengan isolasi virus maupun pemeriksaan IgM capture ELISA dari serum atau CSS dengan sensitivitas hampir 100\%. Terapi JE hanya bersifat simtomatis dan suportif. Pencegahan dan pemberantasan JE virus ditujukan pada manusia, vektor nyamuk Culex beserta larvanya, dan reservoir babi. Penyakit JE dapat dicegah dengan imunisasi. Pada kasus berat, ditemukan gejala sisa sekitar 40\%-75\%.

Kata kunci: Japanese encephalitis, nyamuk Culex, peternakan babi, imunisasi
\end{abstract}

Japanese encephalitis (JE) merupakan penyakit infeksi akut pada susunan saraf pusat (SSP) yang ditularkan melalui nyamuk yang terinfeksi virus JE. Virus JE termasuk dalam famili flavivirus. Penyakit ini pertama kali dikenal pada tahun 1871 di Jepang dan diketahui menginfeksi sekitar 6.000 orang pada tahun 1924. Virus JE pertama kali diisolasi tahun 1934 dari jaringan otak penderita ensefalitis yang meninggal. Pertama kali terjadi kejadian luar biasa (KLB) pada tahun 1935 dan hampir setiap tahun terjadi KLB, dari tahun 1946 hingga tahun $1950 .^{1,2}$

Japanese encephalitis adalah infeksi neurologik yang berkaitan erat dengan St. Louis encephalitis dan West Nile encephalitis. Virus JE menyebar terutama di daerah pedesaan (rural) di Asia. Virus tersebut disebarkan oleh nyamuk culicine: 
nyamuk yang paling sering ditemukan sebagai vektor ialah Culex tritaeniorhynchus yang dapat menularkan virus JE baik ke manusia maupun ke hewan peliharaan lainnya. ${ }^{3,4}$ Penyebaran penyakit ini tergantung musim, terutama pada musim hujan saat populasi nyamuk Culex meningkat, kecuali di Malaysia, Singapura, dan Indonesia (sporadik terutama di daerah pertanian). ${ }^{5}$ Penyakit ini endemik di daerah Asia, mulai dari Jepang, Filipina, Taiwan, Korea, China, Indo China, Thailand, Malaysia, Indonesia, dan India. Diperkirakan terdapat 35.000 kasus JE di Asia setiap tahun. Penyakit ini paling sering menginfeksi anak berusia 1 tahun hingga 15 tahun.,

Di Indonesia, terdapat sekitar 19 jenis nyamuk yang dapat menularkan penyakit ini; paling sering ialah Culex tritaeniorhynchus, yang banyak dijumpai di daerah persawahan, rawa-rawa dan genangan air. ${ }^{7}$ Babi dan unggas yang hidup di air seperti bangau, merupakan hewan utama reservoir virus ini. ${ }^{2,7}$ Selain itu sapi, kuda, kerbau, kambing, tikus, kera, ayam dan kucing juga dapat berperan sebagai reservoir virus JE. ${ }^{2}$ Di Indonesia, penelitian penyakit JE sudah dilakukan sejak tahun 1975 dengan seroprevalensi bervariasi antara $10 \%-75 \%$. ${ }^{5,6}$

Manifestasi neurologik penyakit JE yang disebabkan oleh flavivirus bervariasi, mulai dari adanya sedikit perubahan dalam tingkah laku hingga masalah yang serius termasuk kebutaan, ataksia, kelemahan, dan gangguan gerakan tubuh. ${ }^{3,4}$ Angka kematian berkisar antara 20\% hingga 30\%. Penyakit ini dapat dicegah dengan vaksinasi; beberapa negara seperti Thailand, China, Nepal, India dan Jepang sudah memasukkan imunisasi JE ke dalam program imunisasi rutin sehingga kasus ensefalitis turun bermakna dari 14,7 per 100.000 penduduk menjadi 1 per 100.000 penduduk. $^{8}$

\section{Epidemiologi}

Dewasa ini terdapat 3 milyar orang tinggal di daerah endemis JE, daerah ini meluas dari Pakistan hingga Siberia dan Jepang. ${ }^{5}$

Virus JE termasuk salah satu dari 66 jenis flavivirus. Virus ini termasuk dalam serokompleks JE, yang terdiri dari beberapa flavivirus termasuk Alfuy, Koutango, Kokobera, Kunjin, Murray Valley encephalitis, JE, Stratford, Usutu, West Nile dan St. Louis encephalitis. ${ }^{9}$ Japanese encephalitis merupakan penyakit musiman; kebanyakan kasus terjadi pada bulan Juni hingga September. Pada daerah subtropis, transmisi virus JE terjadi pada bulan Maret hingga Oktober. Transmisi dapat terjadi sepanjang tahun pada daerah tropis seperti Indonesia. Negara yang termasuk daerah endemis penyakit JE ialah Malaysia, Burma, Filipina, Indonesia, China, Taiwan, Rusia (Siberia maritim), Bangladesh, Laos, Kamboja, Thailand, Vietnam, India, Nepal (terutama daerah Terai), Srilanka, Korea, Jepang, Australia (pulau-pulau di Semenanjung Torres), Brunei, Pakistan, Papua Nugini dan Kepulauan Pasifik. ${ }^{5}$ Sebagaimana patogen penyakit zoonotic lainnya, beberapa faktor seperti ekologi, iklim, lingkungan dan perilaku manusia berperan dalam penyebaran distribusi virus JE. Bahkan beberapa nyamuk yang terbawa arus angin telah dipertimbangkan berkontribusi terhadap penyebaran virus, contohnya dari Papua Nugini ke pulau-pulau Semenanjung Torres dan Australia. ${ }^{5}$

Secara global, lebih dari 45.000 kasus dilaporkan setiap tahun, walaupun kemungkinan telah terjadi penurunan perkiraan insiden penyakit yang sesungguhnya. ${ }^{6,7}$ Laju insidens lokal bervariasi mulai dari 1-10 kasus per 100.000 orang, tetapi bisa mencapai lebih dari 100 kasus per 100.000 orang pada saat outbreak. ${ }^{5}$ Nyamuk Culex bersifat zoofilik yaitu lebih menyukai binatang, hanya secara kebetulan saja dapat menyerang manusia terutama bila dalam keadaan densitas Culex yang sangat padat. $^{2}$ Keparahan infeksi yang terjadi secara alamiah dan kemungkinan komplikasi yang berat dapat terjadi menjadi faktor penting 
untuk mempromosikan vaksinasi sebagai pencegahan utama penyakit JE. ${ }^{5}$

Rasio infeksi virus JE asimtomatik dengan infeksi simtomatik bervariasi yaitu 25-1000 berbanding 1 . Rasio kasus penyakit JE simtomatis pada pria dan wanita 1,5:1. Ditemukan bukti adanya infeksi virus JE dari pemeriksaan serologik pada hampir seluruh penduduk usia dewasa muda di daerah pedesaan negara endemis. Japanese encephalitis menyerang semua umur, namun infeksi simtomatis paling sering terjadi pada anak-anak berusia 2 tahun hingga 10 tahun dan pada kelompok geriatri (usia lebih dari 60 tahun). Pada daerah non endemis, infeksi virus JE tidak memiliki predileksi usia., ${ }^{5,7}$ Penyakit JE relatif jarang terjadi di antara para turis yang berpergian ke daerah endemis dalam jangka pendek dan ke daerah urban yaitu $<1$ per 1 juta turis. Individu yang berisiko ialah turis yang menetap di negara endemis dalam jangka panjang di daerah pedesaan di negara endemis.

Di Indonesia, virus JE pertama kali diisolasi dari nyamuk pada tahun 1972 di daerah Bekasi. Endemisitas JE ditemukan di hampir seluruh provinsi di Indonesia, dimana umumnya masyarakat hidup berdekatan dengan hewan ternak mereka. Data dari Kementrian Kesehatan Republik Indonesia (Kemkes RI) tahun 1993-2000 menunjukkan spesimen positif JE ditemukan di 14 Provinsi (Bali, Riau, Jawa Barat, Jawa Tengah, Lampung, Nusa Tenggara Barat, Nusa Tenggara Timur, Sumatera Utara, Kalimantan Barat, Sulawesi Utara, Sulawesi Selatan dan Papua). ${ }^{2}$ Survei di Rumah Sakit (RS) Sanglah Bali pada tahun 1990 hingga tahun 1992 pada 47 kasus ensefalitis ditemukan 19 kasus (40,4\%) serologi positif terhadap penyakit JE. Survei di RS yang sama pada tahun 2001 hingga tahun 2002 pada 262 kasus ensefalitis, ditemukan 112 kasus (42,8\%) positif dengan angka kematian (mortality rate) sebanyak 16\% dan angka kecacatan (sequelae rate) sebanyak $53,1 \%{ }^{6}$

Pada hewan, penyakit ini dapat menyebabkan terjadinya abortus, meninggal, atau bahkan tanpa gejala. Hewan yang dapat terinfeksi penyakit ini ialah ternak lembu, sapi, ayam, bebek dan kambing, dan vertebrata lainnya, termasuk ular, kodok, tikus, dan kelelawar. Burung merupakan hewan yang penting dalam penyebaran penyakit ini. Virus dapat bereplikasi di dalam darah hewan tanpa menimbulkan penyakit serius, yang memungkinkan siklus penularan. Manusia dan kuda merupakan dead-end host, artinya tidak terjadi penularan dari manusia atau kuda ke manusia atau hewan lain melalui gigitan nyamuk. ${ }^{5}$

\section{Etiologi}

Virus JE termasuk dalam genus flavivirus, single-stranded ribonucleid acid (RNA) dan merupakan salah satu etiologi ensefalitis arboviral yang paling signifikan. $^{10}$ Virus JE ditransmisikan ke manusia lewat gigitan nyamuk Culex yang terinfeksi, paling sering ialah nyamuk Culex tritaeniorhynchus. Vektor Culex lainnya ialah Culex vishnui (India), Culex gelidus dan Culex fuscocephala (Thailand, India, Malaysia). Nyamuk tersebut sangat aktif pada sore dan malam hari sehingga risiko infeksi JE paling tinggi pada waktu tersebut. Nyamuk berkembang biak di tempat-tempat penampungan air terutama daerah persawahan sehingga meningkatkan risiko infeksi pada daerah pedesaan. Manusia dan mamalia lainnya seperti kuda merupakan inang terakhir dimana terjadi low grade viremia dan jangka pendek. Babi dan burung akuatik ialah inang perantara dimana terjadi high grade viremia dan persisten serta menjadi reservoir utama virus JE. Kuda dan babi muda dapat mengalami gejala klinis dengan spektrum gejala menyerupai manusia seperti demam, gangguan gerakan, dan konfusi. ${ }^{10}$

Japanese encephalitis disebabkan oleh virus JE, yang termasuk Arbovirus grup B, genus flavivirus, family flaviviridae. Virus ini berbentuk sferis dengan diameter 40-60 $\mathrm{nm}$, inti virion terdiri dari RNA rantai tunggal yang sering bergabung dengan protein disebut nukleoprotein. Sebagai 
pelindung inti virion terdapat kapsid yang terdiri dari polipeptida tersusun simetri ikosahedral yaitu bentuk tata ruang yang dibatasi oleh 20 segi sama sisi, mempunyai aksis rotasi berganda. Di luar kapsid tersebut terdapat selubung. Virus relatif labil terhadap demam, rentan terhadap berbagai pengaruh desinfektan, deterjen, pelarut lemak dan enzim proteolitik. Infektivitasnya paling stabil pada $\mathrm{pH}$ 7-9, namun dapat diinaktifkan oleh radiasi elektromagnetik, eter, dan natrium deoksikolat. $^{2}$

Terdapat 4 varian genotipe utama virus JE yaitu isolat virus JE tipe I (diidentifikasi di China, India, Jepang, Nepal, Srilanka, Taiwan dan Vietnam); isolat virus JE tipe II (diidentifikasi di Kamboja dan Thailand utara); isolat virus JE tipe III (diidentifikasi di Indonesia, Malaysia dan Thailand selatan, penyebaran genotipe ini yang paling luas dibanding genotipe lain); dan isolat virus JE tipe IV (diidentifikasi di Indonesia dan Malaysia). ${ }^{10}$

\section{Patogenesis}

Virus JE awalnya memperbanyak diri di daerah gigitan dan nodus limf regional. Dua karakteristik seluler yang penting dalam patogenesis yaitu protein $M$ yang mengandung domain hidrofobik yang membantu untuk penempelan virus ke dalam sel inang dan protein $E$ yang memiliki fitur imunogenik utama dan diekspresikan ke dalam membran sel yang terinfeksi. Protein E memediasi fusi membran antara envelope virus dengan membran sel sehingga virus dapat masuk ke dalam sel inang. ${ }^{11}$

Siklus replikasi virus JE dimulai dari interaksi virus JE dengan reseptor sel inang, kemudian endositosis yang diperantarai oleh reseptor, fusi dari membran virus dan sel inang, pelepasan genom virus sitoplasmik dan dilanjutkan oleh proses transkripsi dan pre-translasi. Maturasi partikel virus terjadi di dalam kompleks Golgi, diikuti oleh pelepasan virus JE. ${ }^{11}$

Pada tingkat sel, setelah virus JE menempel dengan sel inang, terjadi kerusakan membran lokal sehingga menyebabkan masuknya virus JE ke dalam sel, kemudian terjadi viremia pertama yang umumnya berlangsung sebentar dan sangat ringan. Bila viremia pertama tetap berlangsung maka akan terjadi penyebaran melalui aliran darah dan menimbulkan perubahan inflamatorik pada jantung, paru, hati, sistem retikuloendotelial dan SSP yang dapat menimbulkan penyakit subklinis. Di dalam organ-organ tersebut virus JE akan berkembang biak kemudian akan dilepaskan, masuk kedalam peredaran darah, dan menimbulkan gejala penyakit sistemik. $^{2,11}$

Bentuk subklinis atau ringan dari penyakit JE menghilang dalam beberapa hari, jika tidak melibatkan SSP. Pada kasus tersebut, infeksi bisa tidak menimbulkan gejala dan tetap tidak terdeteksi. Pada kasus lainnya, dimana terjadi invasi virus JE ke SSP yang disebabkan oleh pertumbuhan virus sepanjang sel endotelial vaskular, menyebabkan keterlibatan sejumlah besar area di otak termasuk talamus, ganglia basal, batang otak, serebelum khususnya destruksi sel Purkinje serebelum, hipokampus, dan korteks serebri. Infeksi persisten dan transmisi kongenital dapat terjadi. Semakin tinggi level sitokin tertentu seperti interferon (IFN) alfa, interleukin (IL) 6 dan IL 8, maka semakin tinggi tingkat mortalitasnya. ${ }^{10,11}$

Virus JE dapat meningkatkan terjadinya patologi sistem saraf pusat karena efek neurotoksik langsung ke sel-sel otak dan kemampuannya untuk mencegah perkembangan sel-sel baru dari sel neuron (neural stem/progenitor cells) sehingga meningkatkan morbiditas dan mortalitas. ${ }^{11}$ Bagaimana cara virus dapat menembus sawar darah otak tidak diketahui dengan pasti, namun diduga setelah terjadinya viremia, maka virus akan menembus sawar darah otak dan berkembang biak pada sel endotel dengan cara endositosis Setelah mencapai jaringan SSP, virus berkembang biak di dalam sel dengan cepat pada retikulum endoplasma yang kasar serta badan Golgi dan setelah itu meng- 
hancurkannya. Akibat infeksi virus tersebut maka permeabilitas sel neuron, glia dan endotel meningkat, mengakibatkan cairan di luar sel mudah masuk ke dalam sel dan timbullah edema sitotoksik. Adanya edema dan kerusakan SSP ini memberikan manifestasi klinis berupa ensefalitis. Area otak yang terkena dapat pada talamus, ganglia basal, batang otak, serebelum, hipokampus dan korteks serebral. Bisa juga dengan cara seperti virus neurotropik umumnya yaitu setelah masuknya virus JE ke tubuh manusia terutama setelah viremia yang kedua, tubuh manusia membentuk antibodi antivirus yang beredar dalam darah dan masuk ke SSP menimbulkan proses inflamasi dengan akibat timbulnya edema dan selanjutnya terjadi anoksia, yang pada akhirnya terjadi kematian sel-sel SSP yang luas. ${ }^{2,12}$

Terdapat satu studi yang menyimpulkan bahwa sel-sel sistem saraf pusat selain neuron seperti astrosit dan sel mikroglia juga bisa terkena infeksi viral replikatif karena virus JE, sehingga menyebabkan terjadinya kerusakan pada sawar darah otak (blood-brain barrier). ${ }^{11}$

\section{Gejala klinis}

Manifestasi klinis penyakit JE pada manusia bervariasi, mulai dari gejala ringan seperti demam flu biasa sampai berat bahkan kematian. Pada kasus yang berat, ditemukan gejala sisa pada sekitar $40 \%$ $75 \%$ kasus berupa kelumpuhan, keterbelakangan mental dan penurunan inteligensia. ${ }^{3}$ Tidak semua manusia yang di gigit oleh Culex yang infektif menunjukkan gejala klinis ensefalitis. Penelitian di Jepang memperkirakan 1 kasus menunjukkan gejala klinis ensefalitis dari tiap 5001000 anak yang menderita infeksi JE yang asimtomatik, dengan angka kematian 20\%$40 \%{ }^{2}$ Japanese encephalitis termasuk famili flavivirus yang sama dengan virus dengue, maka perlu dilakukan juga pemeriksaan terhadap virus dengue. ${ }^{3}$ Masa inkubasi penyakit JE bervariasi antara 4 sampai 14 hari. Perkembangan gejala terbagi atas 4 stadium: ${ }^{1-4}$

\section{Stadium prodormal}

Stadium ini berlangsung selama 2-3 hari, mulai dari timbulnya keluhan sampai timbulnya gejala SSP. Gejala yang sangat dominan ialah demam, nyeri kepala dengan atau tanpa menggigil. Gejala lain berupa malaise, anoreksia, keluhan dari traktus respiratorius seperti batuk, pilek dan keluhan gastrointestinal seperti mual, muntah dan nyeri di daerah epigastrium. Nyeri kepala dirasakan di dahi atau seluruh kepala, biasanya hebat dan tidak bisa dihilangkan dengan pemberian analgesik. Demam selalu ada dan tidak mudah diturunkan dengan obat antipiretik, namun mungkin saja seorang pasien JE hanya mengalami demam ringan atau gangguan pernapasan ringan. ${ }^{1-4}$

\section{Stadium akut}

Stadium ini berlangsung selama 3-4 hari, ditandai dengan demam tinggi yang tidak turun dengan pemberian antipiretik. Bila selaput otak telah terinfeksi dan membengkak, maka pasien akan merasakan nyeri serta kekakuan pada leher hingga peningkatan tekanan intra kranial berupa gangguan keseimbangan dan koordinasi, kelemahan otot-otot, tremor, kekakuan pada wajah, nyeri kepala, mual, muntah, kejang, penurunan kesadaran dari apatis hingga koma. Berat badan menurun disertai dehidrasi. $^{1-4}$ Pada kasus ringan mulai penyakitnya perlahan-lahan, demam tidak tinggi, nyeri kepala ringan, demam akan menghilang pada hari ke-6 atau ke-7 dan gejala ekstrapiramidal muncul setelah gejala neurologik lainnya menghilang. Gejala ekstrapiramidal seperti Parkinson berupa wajah menyerupai topeng (masklike facies), tremor, rigiditas dan gerakan choreoathetoid sering terjadi. ${ }^{3,4}$ Kelainan neurologik menyembuh pada akhir minggu ke-2 setelah mulainya penyakit. Pada kasus berat, awitan penyakit sangat akut, kejang menyerupai epilepsi, hiperpireksia, kelainan neurologik yang progresif, penyulit kardiorespirasi dan koma, diakhiri dengan kematian pada hari ke-7 dan ke-10 atau pasien hidup dan membaik dalam 
jangka waktu yang lama, kadang-kadang terkena penyulit infeksi bakteri dan meninggalkan gejala sisa permanen. Kejang dialami oleh sekitar 10\%-24\% penderita anak, sedangkan orang dewasa lebih jarang mengalami kejang. Pada stadium ini pemeriksaan cairan serebrospinal (CSS) menunjukkan leukositosis yang pada awalnya didominasi sel polimorfonuklear (PMN) tetapi setelah beberapa hari menjadi limfositosis. Albuminuria sering ditemukan. ${ }^{1-4}$

\section{Stadium sub akut}

Stadium ini berlangsung selama 7-10 hari. Gejala gangguan SSP berkurang, namun seringkali pasien menghadapi masalah pneumonia ortostatik, infeksi saluran kemih (ISK), dan dekubitus. Gangguan fungsi saraf dapat menetap seperti paralisis spastik, hipotrofi otot sebagai akibat perawatan lama dan pemasangan kateter urin, fasikulasi, gangguan saraf cranial. dan gangguan ekstrapiramidal. $^{1-4}$

\section{Stadium konvalesens}

Stadium ini berlangsung lama, bisa 4-7 minggu dan ditandai dengan kelemahan, letargi, gangguan koordinasi, tremor dan neurosis. Berat badan dapat sangat menurun. Stadium ini dimulai saat menghilangnya inflamasi yaitu pada saat suhu kembali normal. Gejala neurologik bisa menetap dan cenderung membaik. Bila penyakit JE berat dan berlangsung lama maka penyembuhan lebih lambat, tidak jarang sisa gangguan neurologik berlangsung lama. Gejala sisa yang sering dijumpai ialah gangguan mental berupa emosi tidak stabil, paralisis upper atau lower motor neuron..$^{1-4}$

Gejala sisa atau sekuele ditemukan pada 5\%-70\% kasus, umumnya pada anak usia di bawah 10 tahun, dan pada bayi akan lebih berat. Kekerapan terjadinya sekuele berhubungan langsung dengan beratnya penyakit. Sekuele tersebut dapat berupa gangguan pada: ${ }^{2}$

1. Sistem motorik: motorik halus (72\%), kelumpuhan (44\%), gerakan abnormal (8\%).

2. Perilaku: agresif (72\%), gangguan perhatian (55\%), depresi (38\%).

3. Intelektual: abnormal (72\%), retardasi (22\%).

4. Fungsi neurologik lain berupa gangguan ingatan (46\%), afasia (38\%), epilepsi (20\%), paralisis saraf kranial (16\%) dan kebutaan (2\%).

\section{Diagnosis}

Diagnosis JE baru dapat ditegakkan tahun 1981 berdasarkan kriteria World Health Organization (WHO) dan pemeriksaan immune adherence hemaglutinin (IAHA). Secara klinis tidak ada gejala khas untuk JE, maka seringkali diagnosis ditegakkan sebagai ensefalitis tanpa dicari penyebabnya. ${ }^{2}$

\section{Anamnesis}

Pasien dengan infeksi virus JE memiliki riwayat paparan nyamuk di daerah endemis serta daerah sekitar tempat tinggal memiliki kepadatan Culex yang tinggi, banyak babi piaraan, daerah musim tanam padi, atau memasuki musim penghujan. Periode inkubasi 4-15 hari dengan rata-rata 6-8 hari. Periode prodromal ditandai oleh adanya demam tinggi, sakit kepala hebat yang tidak bisa dihilangkan dengan antipiretik, mual, diare, muntah dan mialgia yang dapat berlangsung selama beberapa hari. Setelah itu, terjadi perubahan status mental yang dapat bervariasi mulai dari konfusi ringan hingga agitasi bahkan koma. Kejang terjadi pada $66 \%$ pasien yang terinfeksi, paling sering dialami anak-anak. Sakit kepala dan meningismus lebih sering dialami dewasa. ${ }^{2-4}$

Tremor dan gerakan involunter lainnya umum terjadi dan mutisme juga telah dilaporkan sebagai salah satu gejala penyakit JE yang dapat menyertai. Sindrom paralisis flaccid akut juga dapat terjadi, melibatkan sel-sel spinal anterior sehingga menyebabkan gejala klinis menyerupai penyakit poliomielitis. Demam menghilang pada minggu kedua dan choreoathetosis 
atau gejala ekstrapiramidal berkembang bersamaan dengan hilangnya gejala neurologik lainnya. ${ }^{1,3,4}$

\section{Pemeriksaan fisik}

Gejala neurologik penyakit JE bervariasi. Kelemahan tubuh menyeluruh (generalized weakness), hipertonia dan hiperrefleksia termasuk adanya refleksrefleks patologik sering terjadi. Papiledema dialami pada kurang dari 10\% pasien dan $33 \%$ pasien mengalami gejala-gejala saraf kranial seperti disconjugate gaze dan cranial nerve palsies. Gejala-gejala ekstrapiramidal menyerupai Parkinson juga umum terjadi, termasuk wajah seperti topeng (mask-like facies), tremor, rigiditas dan gerakan choreoathetoid. ${ }^{1,4}$

\section{Pemeriksaan penunjang}

- Pemeriksaan darah lengkap (complete blood count)

Pemeriksaan darah lengkap sering menunjukkan adanya leukositosis sedang dan non spesifik pada minggu pertama penyakit, kemudian diikuti oleh leukopenia relatif. Anemia ringan juga dapat terjadi. Pada satu studi, sebanyak 15\% anak dengan JE mengalami trombositopenia. ${ }^{4}$

- Level natrium serum

Level natrium serum menurun akibat sekresi hormon antidiuretik yang tidak sesuai. ${ }^{4}$

- Tes fungsi hati

Dalam satu studi yang dilakukan pada anak-anak suku Indian selama outbreak JE di Uttar Pradesh pada tahun 2005, ditemukan hasil tes fungsi hati yaitu semua pasien (100\%) mengalami peningkatan kadar aspartate aminotransferase (AST) dan 47,2\% pasien mengalami peningkatan kadar alanine aminotransferase (ALT). ${ }^{13}$

- Isolasi virus

Isolasi virus JE dari spesimen klinis atau identifikasi sekuens viral genetik positif di dalam jaringan, darah atau CSS. Merupakan pemeriksaan baku emas untuk diagnostik JE. ${ }^{4}$
- Magnetic resonance imaging (MRI) dan Computed Tomography (CT) scan MRI dan CT scan sering menunjukkan adanya lesi talamus bilateral dengan perdarahan. Kadangkala ditemukan adanya abnormalitas pada ganglia basal, putamen, pons, medula spinalis dan serebelum. Lesi hiperintens dapat diperhatikan pada area thalamus, serebrum dan serebelum pada T2weighted MRI. ${ }^{3,4}$

- Electroencephalography (EEG)

EEG sering menunjukkan adanya perlambatan gelombang delta yang kontinu dan difus serta pola gelombang delta difus dengan spikes, sedangkan gelombang theta dengan burst suppression. Perubahan EEG tidak berhubungan dengan derajat beratnya penyakit JE maupun luaran penyakit. ${ }^{4}$

- Gambaran histologik

Perubahan gambaran histologik ditemukan di talamus, substansia nigra, batang otak, hipokampus, serebelum, dan medula spinalis berupa degenerasi fokal neuronal dengan proliferasi mikroglia difus dan fokal serta lymphocytic perivascular cuffing. ${ }^{4}$

- Pungsi lumbal

Pungsi lumbal dilakukan untuk mendapatkan sampel CSS sehingga dapat menyingkirkan diagnosis banding penyebab lain dari ensefalitis. Tekanan pembukaan (opening pressure) biasanya normal tetapi dapat juga meningkat. Level protein CSS sedikit meningkat pada kebanyakan kasus, namun seringnya kurang dari 900 mg/dL. Kadar glukosa CSS seringkali normal. Antara 10 dan beberapa ratus sel leukosit mononuklear dapat ditemukan pada pemeriksaan hitung jenis (differential count). Virus JE dapat diisolasi dari darah selama minggu pertama penyakit. Di dalam CSS jarang ditemukan virus, kecuali pada kasus parah atau fatal.,

- Pemeriksaan serologik

Uji diagnostik baku yaitu IgM capture dengan cara ELISA dari serum atau CSS. Sensitivitasnya mendekati $100 \%$ 
bila kedua bahan (serum dan CSS) di periksa. Beberapa reaksi silang dapat timbul dari flavivirus lain seperti virus dengue, West Nile virus serta sesudah vaksinasi JE dan demam kuning. Pemeriksaan serologis lain yang dapat dilakukan adalah pemeriksaan IAHA, Hemagglutination Inhibition (HI), immunofluorecent antibody (IFA) dan complement fixation (CF), namun semuanya membutuhkan sampel serum pada fase akut dan konvalesen supaya dapat melihat kenaikan titer antibodi sebesar 4 kali atau lebih terhadap virus JE. Uji HI dikatakan positif bila titer antibodi serum akut 1/20 atau lebih, sedangkan pada spesimen konvalesens meningkat 4 kali atau lebih. Keunggulan uji HI yaitu hanya memerlukan laboratorium sederhana, reagen mudah didapat serta biayanya relatif murah. Kelemahan uji HI yaitu tidak dapat membedakan JE dari flavivirus lain seperti infeksi dengue dan virus West Nile. ${ }^{2-4}$

Untuk membuat diagnosis JE di daerah endemis infeksi dengue, spesimen serum dan CSS baik yang akut maupun konvalesens diperiksa IgM anti dengue, IgG anti dengue, IgM anti JE dan IgG anti JE. Hasil dinyatakan positif bila lebih besar dari 40 unit. Hanya spesimen dengan anti JE IgM yang lebih besar atau sama dengan 40 unit dapat diklasifikasikan berasal dari pasien JE. Hasil dari semua 4 uji serologik dibandingkan, hasil rata-rata anti dengue IgM dengan anti JE IgM $\geq$ 1 ialah khas infeksi dengue, sedangkan bila hasilnya $<1$ ialah khas untuk infeksi JE. $^{2}$

- Immunoassays

Diagnosis penyakit JE dapat didukung dengan pemeriksaan immunoassay yang menunjukkan adanya antibodi IgM di dalam CSS. Level antibodi serum dapat meningkat hingga 4 kali lipat. Pemeriksaan IgM ELISA dari sampel serum atau CSS ialah tes diagnostik standar untuk penyakit JE. Sensitivitasnya mendekati $100 \%$ ketika baik sampel serum dan CSS diperiksa. Hasil negatif palsu dapat terjadi kalau sampel-sampel yang diperiksa diambil terlalu dini yaitu dalam minggu pertama onset penyakit. ${ }^{3,4}$

Beberapa reaksi silang dapat timbul akibat infeksi flavivirus lainnya seperti dengue dan virus West Nile dan juga pada orang yang telah divaksinasi JE dan yellow fever. Fenomena ini dapat berkontribusi terhadap kejadian misdiagnosis sehingga tes paralel untuk virus JE dan flavivirus lainnya seperti dengue dibutuhkan., ${ }^{1,3}$

Pemeriksaan IgM dot enzyme immunoassays dari sampel CSS dan serum merupakan tes yang sederhana dan portable serta dapat dibandingkan dengan IgM capture ELISA untuk diagnosis pasti (sensitivitas 98,3\% dan spesifisitas 99,2\% ketika dibandingkan dengan IgM capture ELISA sebagai standar). ${ }^{14}$

\section{Pemeriksaan konfirmasi}

\section{Isolasi virus}

Isolasi virus JE dari spesimen klinis atau identifikasi sequence virus genetik positif sering dari jaringan otak dan jarang didapat dari darah dan CSS. Dari darah JE virus dapat diisolasi selama stadium akut, sedangkan dari CSS virus dapat diisolasi pada permulaan ensefalitis. Dari jaringan otak segar pasien yang meninggal pada minggu pertama sakit dapat terdeteksi cukup banyak JE virus. ${ }^{2}$ Isolasi virus merupakan pemeriksaan baku emas untuk mendeteksi JE, namun sangat sulit pada manusia karena masa viremia yang pendek sekali, sehingga saat pasien mengalami gejala klinis, masa viremianya telah berlalu. ${ }^{1,3}$

\section{Pemeriksaan RT-PCR}

Pemeriksaan reserve transcription PCR amplification (RT-PCR) dapat mendeteksi RNA virus JE. Pada metode ini terlebih dahulu dilakukan transkripsi terbalik RNA sasaran menjadi DNA, kemudian 
komplemen DNA dilakukan amplifikasi. Dengan menggunakan oligonukleotida yang spesifik JE, cara ini dapat mendeteksi RNA virus JE dalam jumlah yang sangat sedikit. Kelemahan metode ini sangat mahal serta memerlukan teknik dan peralatan yang rumit. Deteksi RNA virus hanya bermanfaat bila dilakukan pada fase viremia; bila di luar viremia RT-PCR akan memberikan hasil negatif. Spesimen untuk pemeriksaan ini bisa dari darah atau CSS dan dilakukan pada minggu pertama sakit. ${ }^{2}$

\section{Pencitraan}

Pencitraan SSP dapat mendukung diagnosis. Pemeriksaan MRI dan CT-Scan sering memperlihatkan adanya lesi bilateral pada talamus yang disertai perdarahan. Gangia basalis, putamen, pons, medulla spinalis dan serebelum juga terlihat abnormal. $^{2}$

\section{Pemeriksaan histologik}

Pada pemeriksaan histologik terdapat perubahan pada talamus, substansia nigra, batang otak, hipokampus, serebelum dan medula spinalis, termasuk degenerasi fokal saraf dengan proliferasi difus dan fokal mikroglia dan perivascular lymphocytic cuffing. ${ }^{2}$

\section{Pemeriksaan immunocytochemistry}

Dilakukan dengan pewarnaan jaringan untuk melihat adanya protein spesifik, dalam hal ini adalah JE. Cara ini dapat mendiagnosis kasus JE yang fatal bila uji serologi dan isolasi virus tidak dapat dilakukan. $^{2}$

\section{Diagnosis banding}

Manifestasi klinis JE dapat ditemukan pada penyakit lain terutama yang berkaitan dengan kelainan SSP seperti malaria serebral, meningitis bakteri, meningitis aseptik, ensefalitis oleh Flavivirus lain, kejang demam, rabies, sindrom Reye dan ensefalopati toksik. ${ }^{2}$ Beberapa diagnosis banding dapat disingkirkan dengan adanya tanda atau gejala yang khas atau pemeriksaan khusus, misalnya: ${ }^{2}$

- Meningitis tuberkulosis: uji Mantoux positif, biakan basil tahan asam (BTA) dari CSS positif

- Meningitis bakterialis: CSS purulen

- Herpes zoster: kelumpuhan saraf kranial satu sisi

- Leptospirosis: ikterus, hepatosplenomegali

\section{Terapi}

Sejauh ini belum ada agen antivirus yang jelas efektif untuk penyakit JE, sehingga fokus terapi penyakit ini terutama simtomatis dan suportif meliputi pemeliharaan jalan napas, pemberian oksigen walaupun tidak ada tanda sianosis, pemantauan sirkulasi darah, pencegahan kelebihan cairan, dan pemantauan gula darah karena sering terjadi hiperglikemia. ${ }^{2-4}$ Prinsip tatalaksana penyakit JE ialah pemberian makan (feeding), penanganan airway, dan antikonvulsan untuk kontrol kejang., ${ }^{2,4}$ Bila terjadi edema otak dapat diberikan deksametasone intravena dosis tinggi $1 \mathrm{mg} / \mathrm{kgbb} / \mathrm{hari}$ dalam 4 dosis selama beberapa hari lalu di tapering off. Deksametasone berfungsi memperbaiki integritas membran sel. Jika ditemukan tanda-tanda peningkatan tekanan intrakranial diberikan manitol; jika memungkinkan, periksa cairan otak. Untuk menurunkan tekanan intrakranial dapat diberikan manitol hipertonik 20\% dosis 0,25-1 $\mathrm{g} / \mathrm{kgbb}$ melalui infus intravena selama 10-30 menit dan dapat diulangi tiap 4-6 jam. Selain itu anak ditidurkan setengah duduk dalam posisi netral dengan kepala lebih tinggi $20^{\circ}-30^{\circ}$ untuk meningkatkan aliran darah pada pembuluh darah balik dan pemberian cairan yang mengandung glukosa $10 \%$ untuk mempertahankan fungsi metabolisme otak. ${ }^{2}$ Dalam seting ruang perawatan intensif (RPI), tekanan perfusi serebral (tekanan arterial rata-rata dikurangi tekanan intrakranial) harus dipertahankan lewat modulasi tekanan darah sistemik yang sesuai. ${ }^{4}$ 
Bila demam dapat diberikan antipiretik seperti parasetamol dan asetosal. Selain itu dapat diberikan tindakan suportif yaitu istirahat dan kompres. Istirahat diperlukan karena bila beraktivitas maka aktivitas otot akan meningkatkan metabolisme yang selanjutnya akan menambah tinggi suhu tubuh. Kompres hangat juga akan membantu pengeluaran panas terutama melalui paru dan kulit melalui cara konduksi, konveksi, dan penguapan air melalui kelenjar keringat. Tidak dibenarkan melakukan kompres dengan alkohol karena bisa menyebabkan depresi SSP diakibatkan anak menghirup uap alkohol. ${ }^{2}$

Bila pasien kejang, dilakukan penanganan kejang pada umumnya berupa diazepam intravena, dosis 0,3-0,5 $\mathrm{mg} / \mathrm{kgbb} / \mathrm{kali}$ dengan dosis maksimal pada anak berusia $<5$ tahun $5 \mathrm{mg}$; anak usia 5-10 tahun 7,5 mg; dan >10 tahun 10 mg dengan kecepatan pemberian $1 \mathrm{mg} /$ menit. Bila anak tetap kejang dosis di atas dapat diulangi sekali lagi setelah 15 menit. ${ }^{2}$ Bila diazepam intravena tidak tersedia dapat diberikan diazepam rektal $5 \mathrm{mg}$ pada anak dengan berat badan $<10 \mathrm{~kg}$ dan diazepam rektal $10 \mathrm{mg}$ pada anak dengan berat badan $\geq 10 \mathrm{~kg}$. Bila kejang sudah berhenti dapat dilanjutkan dengan pemberian fenobarbital oral $5 \mathrm{mg} / \mathrm{kgbb} / \mathrm{kali}$ di bagi dalam 2 dosis. Bila sebelumnya pasien menunjukkan kejang lama atau status konvulsi, setelah kejang berhenti diberikan bolus fenobarbital intramuskular dosis awal 50 mg untuk anak berusia 1 bulan- 1 tahun dan $75 \mathrm{mg}$ untuk anak berusia $>1$ tahun. Setelah lebih dari 4 jam disusul pemberian fenobarbital oral dengan dosis rumatan 8 $\mathrm{mg} / \mathrm{kgbb} / \mathrm{hari}$ dibagi dalam 2 dosis selama 2 hari dan selanjutnya $4-5 \mathrm{mg} / \mathrm{kgbb} / \mathrm{hari}^{2}{ }^{2}$

Faktor yang paling penting untuk penanganan peningkatan tekanan intrakranial ialah mengidentifikasi dan menginisiasi intervensi terapeutik yang sesuai. Pasien dengan penyakit JE harus dimonitor secara ketat terhadap komplikasi yang dapat menyertai, termasuk infeksi bakterial seperti pneumonia, infeksi salluran kencing (ISK), atau ulkus dekubitus. Klinisi juga harus berhati-hati terhadap ko-infeksi dengan penyakit tropis lainnya seperti penyakit tuberkulosis dan malaria. Selain itu, perlu dilakukan pencegahan terjadinya dekubitus, pencegahan kerusakan kornea, mengurangi rangsangan eksternal, pemberian cairan dan suplemen berupa vitamin dan mikronutrien, pemberian antibiotik untuk infeksi sekunder, fisioterapi, dan rehabilitasi untuk pasien yang dirawat dalam jangka panjang maupun pada pasien yang sembuh dengan defisit neurologis. ${ }^{3,4}$

\section{Prognosis}

Hanya 1 per 250 infeksi virus JE menyebabkan penyakit simtomatis. Prognosis infeksi virus JE simtomatis bervariasi. Terdapat dua faktor yang menandakan prognosis baik yaitu konsentrasi antibodi penetralisir yang tinggi di dalam CSS dan level IgG virus JE yang tinggi di dalam CSS. ${ }^{3,4}$ Faktor risiko kematian yang terbukti di antaranya ialah ditemukan virus di dalam CSS, kadar protein yang tinggi pada CSS menyebabkan prognosis kurang baik, level IgG dan/atau IgM rendah di dalam CSS atau serum dan penurunan sensorium. ${ }^{3,4}$

Beberapa prognosis buruk infeksi virus JE di antaranya ialah pasien berusia kurang dari 10 tahun karena gejala sisa biasanya lebih sering, Glasgow Coma Scale (GCS) rendah, hiponatremia, syok, ditemukannya kompleks imun di dalam cairan serebrospinal, peningkatan jumlah antibodi antineurofilamen, peningkatan level tumor necrosis factor (TNF) dan adanya neurosistiserkosis. ${ }^{3,4}$ Selain itu demam tinggi yang berlangsung lama, kejang hebat dan sering disertai depresi pernapasan yang timbul dini akan mengakibatkan prognosis buruk. ${ }^{2}$ Riwayat infeksi dengue sebelumnya berhubungan dengan penurunan laju morbiditas dan mortalitas, yang mungkin disebabkan oleh proteksi parsial reaksi silang antibodi antiflaviviral. $^{4}$

Infeksi virus JE pada kehamilan trimester pertama atau kedua dapat menyebabkan kematian fetus. Infeksi pada 
trimester ketiga, walaupun belum dievaluasi secara sistematis, namun nampaknya berhubungan dengan luaran fetus normal. ${ }^{4}$ Kira-kira $33 \%-50 \%$ pasien yang mengalami penyakit simptomatis memiliki sekuele neurologik mayor dalam 1 tahun, termasuk kejang, paresis saraf kranial atau saraf motorik, dan gangguan gerak. Laju mortalitas pada daerah yang kurang berkembang bisa melebihi 35\%. Secara keseluruhan di seluruh dunia, lebih dari 10.000 kematian akibat penyakit JE dilaporkan setiap tahun. ${ }^{5}$

\section{Pencegahan}

Pencegahan dan pemberantasan JE ditujukan pada manusia, vektor nyamuk Culex beserta larvanya dan reservoir babi. Penyakit ini dapat dicegah dengan imunisasi. Tujuan dilakukan pengontrolan yaitu untuk meminimalkan kemungkinan terjadinya infeksi JE. ${ }^{2,15}$ Beberapa negara seperti Thailand, China, Nepal, India dan Jepang sudah memasukkan imunisasi JE ke dalam salah satu program imunisasi rutin. ${ }^{8}$

Terdapat 3 jenis vaksin JE yang digunakan di seluruh dunia yaitu inactivated mouse brain vaccine (strain Nakayama dan Beijing 1), inactivated primary hamster kidney cell vaccine (strain P3), dan live attenuated primary hamster kidney cell vaccine (strain $\mathrm{SA}_{14}-14-2$ ). Ketiga-tiganya telah digunakan untuk virus JE genotipe III tetapi memiliki proteksi silang (cross-protective) melawan genotipe lainnya. ${ }^{5}$

Imunisasi juga dianjurkan untuk orang yang bepergian ke daerah endemik JE. Vaksin yang beredar saat ini ialah JE-Vax dari Jepang (Biken), Korea (Green Cross), dan $\mathrm{SA}_{14}-14-2$ (China). Pemberian vaksin secara subkutan. Vaksin $\mathrm{SA}_{14}-14-2$ memiliki keuntungan dibandingkan dengan vaksin lainnya karena cukup satu dosis saja dan mampu memberikan respon antibodi 83\%-100\% pada anak berusia 6-7 tahun. Pada anak usia lebih tua dilakukan vaksinasi sebanyak dua kali dengan selang waktu antara 1 sampai 3 bulan serta memberikan respon antibodi yang cukup tinggi (94-100\%). Selain vaksinasi terhadap manusia, terdapat juga vaksinasi untuk hewan terutama kuda dan ternak lainnya. ${ }^{16}$

Jadwal dan dosis vaksin JE saat ini ialah untuk pasien berusia 3 tahun ke atas 1 mL secara subkutan pada hari 0,7 dan 30, sedangkan untuk pasien berusia 1-2 tahun, diberikan dosis $0,5 \mathrm{~mL}$. Jadwal vaksinasi hari 0, 7 dan 14 dapat dipertimbangkan jika waktu yang tersedia sebelum bepergian tidak dapat memenuhi interval dosis vaksin yang lebih lama. Pasien dengan jadwal vaksinasi yang lebih pendek cenderung memiliki titer antibodi yang lebih rendah pada bulan kedua dan bulan keenam setelah imunisasi dibandingkan dengan pasien yang divaksinasi dengan jarak antar vaksinasi lebih lama, walaupun laju serokonversi hampir serupa. ${ }^{4,17}$

Kebutuhan akan dosis booster masih belum jelas tetapi dapat dipertimbangkan 36 bulan atau lebih lama setelah dosis ketiga. Pilihan kedua yang mungkin dapat dilakukan ialah dengan mengikuti titer antibodi dan revaksinasi ketika titer antibodi turun sampai kurang dari 1:10. Dosis terakhir vaksin diberikan minimal 10 hari sebelum bepergian ke daerah endemis. Wanita hamil perlu divaksinasi hanya bila mereka termasuk dalam kelompok risiko tinggi terpapar virus JE karena sangat berisiko terjadi angioedema. ${ }^{17}$

Efek samping vaksinasi yang ringan dilaporkan sebanyak hampir 20\% dari penerima vaksin, yaitu berupa nyeri dan kemerahan lokal, demam, gejala gastrointestinal, sakit kepala dan mialgia. Insidens reaksi-reaksi tersebut biasanya berkurang pada dosis selanjutnya. Hipersensitivitas, termasuk angioedema atau urtikaria terjadi pada $0,6 \%$ pasien dan sebanyak $2,6 \%$ per 100.000 penerima vaksin membutuhkan perawatan di RS. Hipersensitivitas vaksin merupakan kontraindikasi utama penggunaan vaksin. Reaksi hipersensitivitas dapat terjadi paling lambat 10-14 hari setelah dosis terakhir. Untuk mempersiapkan diri terhadap kemungkinan terjadinya reaksi hipersensitivitas yang lambat, pasien harus memiliki akses terhadap pelayanan medis selama 10 hari 
setelah dosis terakhir. Pasien-pasien dengan riwayat alergi atau urtikaria memiliki risiko efek samping vaksinasi yang lebih tinggi. ${ }^{17}$

Vaksin JE direkomendasikan untuk wisatawan yang berencana akan tinggal di daerah endemik dan epidemik penyakit JE dan untuk wisatawan yang berencana untuk berwisata dalam jangka panjang yaitu sekitar 30 hari di area pedesaan. Wisatawan yang mengunjungi daerah epidemik aktif untuk penyakit JE harus dipertimbangkan untuk mendapatkan vaksinasi walaupun lama tinggal di daerah tersebut kurang dari 30 hari. Vaksinasi untuk orang-orang yang tinggal dalam jangka waktu kurang dari 30 hari perlu dipertimbangkan jika diperkirakan mereka sering berada di luar ruangan dan saat malam hari tanpa perlindungan. Kelompok berisiko lainnya yang perlu mendapatkan vaksinasi ialah pekerja laboratorium yang memiliki paparan potensial terhadap virus JE. ${ }^{4,17}$ CDC barubaru ini merekomendasikan bagi para wisatawan muda berusia 2 bulan hingga 16 tahun untuk divaksin melawan JE jika hendak berkunjung ke daerah endemis penyakit tersebut. Rekomendasi ini diikuti persetujuan oleh FDA pada Mei 2013 untuk memperluas pemakaian vaksin JE strain $\mathrm{SA}_{14}-14-2$ (Ixiaro) sebagai satusatunya vaksin JE yang tersedia di Amerika Serikat (AS) untuk anak berusia 2 bulan hingga 16 tahun. ${ }^{18}$

Pencegahan paling penting pada wisatawan yang akan mengunjungi daerah endemis ialah menghindari paparan nyamuk, khususnya pada malam hari. Sangat dianjurkan penggunaan kelambu nyamuk ketika tidur dan mosquito repellent dengan diethyltoluamide (DEET) pada saat tertentu, dimana risiko kontak dengan nyamuk-nyamuk terinfeksi berada. ${ }^{19}$ Selain itu perlu dilakukan pemberantasan larva nyamuk Culex dengan cara melakukan pengaturan pengaliran air sehingga larva terbunuh. Juga penggunaan larvasida seperti fenitrotion $1 \%$ dengan dosis 30 $\mathrm{kg} / \mathrm{ha}$ dan fention 0,01-0,04 kg/ha masih sangat efektif untuk membunuh larva. Diperlukan juga pengaturan pembangunan kandang babi yang jauh dari perumahan penduduk dan kandang babi tersebut sering dibersihkan dan diusahakan bebas dari nyamuk Culex. ${ }^{2}$

Standard surveilans WHO untuk uji berbasis lapangan (field-based testing) untuk virus JE telah dipublikasikan. Sampel-sampel CSS yang didapatkan pada saat infeksi akut telah terbukti lebih bermanfaat dibandingkan dengan sampel serum yang didapatkan pada saat infeksi non akut ( $>70 \%$ pasien dengan penyakit JE didiagnosis dengan pemeriksaan CSS). ${ }^{20}$

\section{Simpulan}

Japanese encephalitis (JE) merupakan penyakit infeksi akut pada SSP yang ditularkan melalui nyamuk Culex tritaeniorhynchus yang terinfeksi virus JE dan sering menginfeksi anak berusia 1 tahun hingga 15 tahun. Endemisitas JE ditemukan di 14 provinsi di Indonesia, termasuk Sulawesi Utara. Babi dan unggas merupakan reservoir virus ini. Tidak terjadi penularan dari manusia ke manusia melalui gigitan nyamuk. Manifestasi klinis penyakit JE pada manusia bervariasi, mulai dari gejala ringan seperti demam flu biasa sampai berat bahkan kematian. Pada kasus yang berat, ditemukan gejala sisa pada sekitar 40\%-75\%. Diagnosis pasti dengan isolasi virus, sedangkan pemeriksaan IgM capture dengan cara ELISA dari serum atau CSS mempunyai sensitivitas hampir $100 \%$. Terapi JE hanya bersifat simtomatis dan suportif. Pencegahan dan pemberantasan virus JE ditujukan pada manusia, vektor nyamuk Culex beserta larvanya dan reservoir babi. Penyakit JE dapat dicegah dengan imunisasi.

\section{DAFTAR PUSTAKA}

1. Bromm AK, Smith DW. Arbovirus infections. In: Cook GC, Zumla AI, editors.. Manson's Tropical Diseases (21st ed). Philadelphia: Saunders, 2003; p. 725-95.

2. Soedarma SP, Garna H, Hadinegoro SR, Satara IH. Japanese Encephalitis. In: Soedarma SP, Garna H, Hadinegoro SR, Satara IH, editors. Buku Ajar 
Infeksi dan Pediatri Tropis (2nd ed). Jakarta: Badan penerbit IDAI, 2008; p. 259-75.

3. Halstead SB, Jacobson J. Japanese Encephalitis. Adv Virus Res 2003;61:103-38.

4. Halstead SB. Arbovirus of the Pacific and Southeast Asia. In: Feigin RD, Cherry JD, editors. Textbook of Pediatric Infectious Diseases (2nd ed). Philadelphia: WB Saunders, 1987; p. 1502-8.

5. Endy TP, Nisalak A. Japanese encephalitis virus: ecology and epidemiology. Curr Top Microbiol Immunol. 2002;267:1147.

6. Indonesia. Direktorat Jendral P2MPL Subdit Zoonosis. Laporan serosurvey Japanese Encephalitis. Jakarta: Departemen Kesehatan; 1993/1994-2003.

7. Yoshida M, Igarashi A, Suwendra $P$, Inada $K$, Maha MS, Kari $K$, et al. The first report on human cases serologically diagnosed as Japanese encephalitis in Indonesia. The Southeast Asian J Trop Med Publ Health 1999;30(4):698-706.

8. WHO [Internet]. Immunization, Vaccines and Biologicals: Japanese Encephalitis, 2004 [cited 20167 Jan]. Available from: http://www.who.int/vaccinesdiseases/diseases/je.shtml.

9. Vazquez A, Jimenez-Clavero M, Franco L, Danoso-Mantke O, Sambri V, Niedrig M, et al. Usutu virus: potential risk of human disease in Europe. Euro Surveill. 2011:1-5.

10. Richman DD, Whitley RJ, Hayden FG. Clinical Virology. New York, NY: Churchill Livingstone, 1997.

11. Unni SK, Ružek D, Chhatbar C, Mishra R, Johri MK, Singh SK. Japanese encephalitis virus: from genome to infectome. Microbes Infect. 2011;13(4): 312-21.

12. Thongtan $T$, Cheepsunthorn $P$, Chaiworakul V, Rattanarungsan C, Wikan N, Smith DR. Highly permissive infection of microglial cells by Japanese encephalitis virus: a possible role as a viral reservoir. Microbes Infect. 2010;12(1):3745.

13. Kumar R, Tripathi P, Singh S, Bannerji G. Clinical features in children hospitalized during the 2005 epidemic of Japanese encephalitis in Uttar Pradesh, India. Clin Infect Dis. 2006; 43(2):123-31.

14. Solomon T, Thao LT, Dung NM, Kneen R, Hung NT, Nisalak A, et al. Rapid diagnosis of Japanese encephalitis by using an immunoglobulin $\mathrm{M}$ dot enzyme immunoassay. J Clin Microbiol. 1998;36(7):2030-4.

15. Morita K, Nabeshima T, Buerano CC. Japanese encephalitis. Rev Sci Tech 2015;34(2):441-52.

16. Yang SE, Pan MJ, Tseng HF, Liau MY. The efficacy of mouse-brain inactivated Nakayama strain Japanese encephalitis vaccine-results from 30 years experience in Taiwan. Vaccine. 2006;24(14):2669-73.

17. Schiøler KL, Samuel M, Wai KL. Vaccines for preventing Japanese encephalitis. Cochrane Database Syst Rev. 2007;3:CD004263.

18. Lowry F. Traveling children should get Japanese Encephalitis vaccine. Medscape Medical News. Jun 192013. [cited 2016 Jan 5]. Available from: http://www.medscape. com/viewarticle/806601.

19. Saxena SK, Mathur A, Srivastava RC. Inhibition of Japanese encephalitis virus infection by diethyldithiocarbamate is independent of its antioxidant potential. Antivir Chem Chemother. 2003;14(2):91-8.

20. Solomon T, Thao TT, Lewthwaite $P$, Ooi MH, Kneen R, Dung NM, et al. A cohort study to assess the new WHO Japanese encephalitis surveillance standards. Bull World Health Organ. 2008;86(3):178-86. 